\title{
TU/e emonownen

\section{High-rate deposition of a-SiNx:H for photovoltaic applications by the expanding thermal plasma}

\section{Citation for published version (APA):}

Kessels, W. M. M., Hong, J., Assche, van, F. J. H., Moschner, J. D., Lauinger, T., Soppe, W. J., Weeber, A. W., Schram, D. C., \& Sanden, van de, M. C. M. (2002). High-rate deposition of a-SiNx:H for photovoltaic applications by the expanding thermal plasma. Journal of Vacuum Science and Technology A: Vacuum, Surfaces, and Films, 20(5), 1704-1715. https://doi.org/10.1116/1.1497992

DOI:

10.1116/1.1497992

Document status and date:

Published: 01/01/2002

\section{Document Version:}

Publisher's PDF, also known as Version of Record (includes final page, issue and volume numbers)

\section{Please check the document version of this publication:}

- A submitted manuscript is the version of the article upon submission and before peer-review. There can be important differences between the submitted version and the official published version of record. People interested in the research are advised to contact the author for the final version of the publication, or visit the $\mathrm{DOI}$ to the publisher's website.

- The final author version and the galley proof are versions of the publication after peer review.

- The final published version features the final layout of the paper including the volume, issue and page numbers.

Link to publication

\section{General rights}

Copyright and moral rights for the publications made accessible in the public portal are retained by the authors and/or other copyright owners and it is a condition of accessing publications that users recognise and abide by the legal requirements associated with these rights.

- Users may download and print one copy of any publication from the public portal for the purpose of private study or research.

- You may not further distribute the material or use it for any profit-making activity or commercial gain

- You may freely distribute the URL identifying the publication in the public portal.

If the publication is distributed under the terms of Article $25 \mathrm{fa}$ of the Dutch Copyright Act, indicated by the "Taverne" license above, please follow below link for the End User Agreement:

www.tue.nl/taverne

Take down policy

If you believe that this document breaches copyright please contact us at:

openaccess@tue.nl

providing details and we will investigate your claim. 


\title{
High-rate deposition of $a-\mathrm{SiN}_{x}: \mathrm{H}$ for photovoltaic applications by the expanding thermal plasma
}

\author{
W. M. M. Kessels, $\left.{ }^{a}\right)$ J. Hong, and F. J. H. van Assche \\ Department of Applied Physics, Eindhoven University of Technology, P.O. Box 513, \\ 5600 MB Eindhoven, The Netherlands \\ J. D. Moschner and T. Lauinger ${ }^{\text {b) }}$ \\ Institut für Solarenergieforschung Hameln-Emmerthal (ISFH), Am Ohrberg 1, D-31860, \\ Emmerthal, Germany \\ W. J. Soppe and A. W. Weeber \\ ECN Solar Energy, P.O. Box 1, NL 1755 ZG Petten, The Netherlands
}

D. C. Schram and M. C. M. van de Sanden

Department of Applied Physics, Eindhoven University of Technology, P.O. Box 513, 5600 MB Eindhoven, The Netherlands

(Received 28 February 2002; accepted 10 June 2002)

\begin{abstract}
Driven by the need for improvement of the economical competitiveness of photovoltaic energy, the feasibility of high-rate $(>1 \mathrm{~nm} / \mathrm{s})$ amorphous silicon nitride $\left(a-\mathrm{SiN}_{x}: \mathrm{H}\right)$ deposited by the expanding thermal plasma (ETP) technique has been explored with respect to the application of the $a-\mathrm{SiN}_{x}: \mathrm{H}$ as functional antireflection coating on crystalline silicon solar cells. First, the deposition rate and the $a-\mathrm{SiN}_{x}: \mathrm{H}$ film properties, such as refractive index, $\mathrm{Si}, \mathrm{N}$, and $\mathrm{H}$ atomic density, and hydrogen bonding configurations, have been mapped for various operating conditions. From ellipsometry, elastic recoil detection, and infrared spectroscopy, it has been shown that deposition rates up to 20 $\mathrm{nm} / \mathrm{s}$ can be reached with a fair film homogeneity and that the refractive index and the N/Si ratio can fully be tuned by the plasma composition while the hydrogen content can be controlled by the substrate temperature. Good antireflection coating performance of the $a-\mathrm{SiN}_{x}: \mathrm{H}$ has therefore been observed for monocrystalline silicon solar cells. These cells with ETP $a$-SiN $x: \mathrm{H}$ yielded only slightly lower conversion efficiencies than high-quality reference cells due to a much lower degree of surface passivation. This lack of surface passivation has also been shown in a separate study on the surface recombination velocity. Furthermore, it has been tested whether the $a-\mathrm{SiN}_{x}: \mathrm{H}$ films lead to silicon bulk passivation, which is essential for solar cells based on cheaper, defective silicon stock material such as multicrystalline silicon. It has been proven that bulk passivation of the cells is indeed induced by the high-rate ETP deposited $a-\mathrm{SiN}_{x}: \mathrm{H}$ after a high-temperature step in which the metal contacts of the cells are processed. These results make the ETP technique an interesting candidate for high-throughput processing of competitive silicon solar cells. (C) 2002 American Vacuum Society. [DOI: 10.1116/1.1497992]
\end{abstract}

\section{INTRODUCTION}

Hydrogenated amorphous silicon nitride $a-\mathrm{SiN}_{x}: \mathrm{H}$ deposited by plasma enhanced chemical vapor deposition (PECVD) has, besides a variety of applications in microelectronics, ${ }^{1}$ an important application in photovoltaics. For crystalline silicon $(c-\mathrm{Si})$ solar cells (either made from monocrystalline, multicrystalline, or ribbon silicon wafers) the application of a thin $a-\operatorname{SiN}_{x}: \mathrm{H}$ film can in principle meet three purposes at once., ${ }^{2,3}$ First of all, the combination of the refractive index $n$ of $a-\operatorname{SiN}_{x}: \mathrm{H}$, which is in the range of $\sim 1.8-2.5$, together with its relatively high band gap $(\sim 2-5$ $\mathrm{eV}$ ) makes the material very well suited as antireflection (AR) coating. The refractive index of $a-\mathrm{SiN}_{x}: \mathrm{H}$ can easily be optimized for optimal AR performance and it makes the

\footnotetext{
${ }^{a)}$ Electronic mail: w.m.m.kessels@tue.nl

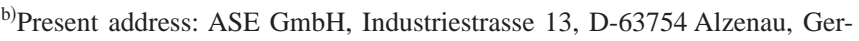
many.
}

material a good alternative for the conventionally applied titaniumoxide $\left(\mathrm{TiO}_{x}\right)$ AR coatings $(n=\sim 2.3)$ fabricated by atmospheric pressure CVD (APCVD). Second, $a-\mathrm{SiN}_{x}: \mathrm{H}$ films can reduce the recombination of charge carriers at the surface of solar cells. This surface passivation effect, which is not obtained by $\mathrm{TiO}_{x}$ films, is especially important for high efficiency and very thin $c$-Si solar cells. The $a-\mathrm{SiN}_{x}: \mathrm{H}$ is therefore preferred over a thermally grown oxide $\left(\mathrm{SiO}_{2}\right)$ which leads to excellent surface passivation but which does not provide efficient AR performance because of the its low refractive index $(n=\sim 1.46) .{ }^{4,5}$ Furthermore, thermal $\mathrm{SiO}_{2}$ formation requires high processing temperatures $\left(>800^{\circ} \mathrm{C}\right)$ while PECVD of $a-\mathrm{SiN}_{x}: \mathrm{H}$ can take place at relatively low temperatures $\left(200-400{ }^{\circ} \mathrm{C}\right)$. This reduces production costs and prevents thermal damage to solar cell devices. Third, the application of $a-\mathrm{SiN}_{x}: \mathrm{H}$ can lead to hydrogen passivation of impurities, defects, and grain boundaries in the Si bulk which is an important issue for multicrystalline silicon $\mathrm{mc}-\mathrm{Si}$ and ribbon Si solar cells. Despite the lower efficiencies of these 
types of cells compared to monocrystalline Si cells, they are the most promising candidates in $c$-Si solar technology for the next decades because of the lower material costs. The hydrogen passivation occurs by atomic hydrogen either present during the deposition process of the $a-\mathrm{SiN}_{x}: \mathrm{H}$ film itself or by hydrogen released from the $a-\mathrm{SiN}_{x}: \mathrm{H}$ film during high temperature steps after deposition, e.g., during firing of the metal contacts. ${ }^{6-11}$ It is obvious that this hydrogen bulk passivation does not take place when thermally grown $\mathrm{TiO}_{x}$ and $\mathrm{SiO}_{2}$ layers are applied.

The nonstochiometric $a-\mathrm{SiN}_{x}: \mathrm{H}$ is clearly a very important material for the $c$-Si solar cell technology. ${ }^{3}$ The application of $a-\mathrm{SiN}_{x}: \mathrm{H}$ with respect to the three above-mentioned purposes has different demands on the properties of the material which depend strongly on the atomic composition of the film in terms of concentrations of N, Si, and H. For AR coatings, $a-\mathrm{SiN}_{x}: \mathrm{H}$ requires a refractive index between 2.0 and 2.3 while the thickness should be in the range of 70-80 $\mathrm{nm}$ (optimum AR coating for unencapsulated cell: $80 \mathrm{~nm}$ thick with $n=2.0$; encapsulated cell: $70 \mathrm{~nm}$ thick with $n$ $=2.3) \cdot{ }^{12}$ To obtain optimum surface passivation for the cells, generally $a-\mathrm{SiN}_{x}: \mathrm{H}$ is required with an even higher refractive index $(n \geqslant 2.3){ }^{2,4,13,14}$ However, for such films considerable light absorption takes place and therefore a compromise between a high surface passivation quality and weak absorbing AR coating is generally obtained for films with $n$ $=\sim 2.2 .^{2}$ So, contrary to the applications of silicon nitride in microelectronics that generally require very $\mathrm{N}$-rich silicon nitride with superior dielectric behavior, a refractive index of $\sim 1.8$, and a $\mathrm{N} / \mathrm{Si}$ ratio equal to the stochiometric limit of $1.33,{ }^{1,15}$ photovoltaic applications require generally only slightly N-rich and even Si-rich $a-\mathrm{SiN}_{x}: \mathrm{H}$ films. For achieving optimum bulk passivation by the $a-\mathrm{SiN}_{x}: \mathrm{H}$, real requirements for the $a-\mathrm{SiN}_{x}: \mathrm{H}$ are not yet known for the moment, however, it is evident that the $a-\mathrm{SiN}_{x}: \mathrm{H}$ films should contain a sufficient hydrogen concentration to make hydrogen diffusion into the mc-Si or ribbon $\mathrm{Si}$ cells possible.

Because the application of $a-\mathrm{SiN}_{x}: \mathrm{H}$ is an additional process step in the production of solar cells, which itself is part of the highly competitive energy market, there are some very strict technological and economic requirements on the $a-\mathrm{SiN}_{x}: \mathrm{H}$ production techniques. Most plasma-assisted deposition techniques use gas mixtures of silane $\left(\mathrm{SiH}_{4}\right)$ and ammonia $\left(\mathrm{NH}_{3}\right)$ which are generally decomposed by lowfrequency $(10-500 \mathrm{kHz}$, lf-PECVD) or radio-frequency (13.56 MHz, rf PECVD) excitation in a capacitively coupled parallel plate plasma reactor. ${ }^{1}$ In addition to these direct plasma techniques, recently also more remote types of plasmas have gained importance, such as microwave plasmas $(2.45 \mathrm{GHz})^{13,16}$ and inductively coupled plasmas. ${ }^{9,17}$ With respect to the AR performance, no clear preferences for a certain plasma technique have been revealed. This is probably due to the fact that only the optical properties and therefore the film composition is of importance for AR coatings and the film composition can usually easily be altered by the plasma composition. Good surface passivation has been obtained with both rf PECVD and remote microwave plasmas, although remote techniques seem to have some significant advantages over the direct techniques in this respect. ${ }^{2,3,16,18}$ For example, a record low surface recombination velocity of the minority charge carriers has been obtained by a remote microwave PECVD technique (generally denoted as RPECVD). ${ }^{4}$ In this latter technique, microwave excited $\mathrm{NH}_{3}$ is used to decompose downstream injected $\mathrm{SiH}_{4}$. On the other hand, If PECVD has not yet been successful in depositing $a-\mathrm{SiN}_{x}: \mathrm{H}$ with good surface passivation properties mainly due to the poor UV stability of the films. This has been attributed to the severe ion bombardment of the film during the if PECVD process creating interface defects. ${ }^{18-20}$ Bulk passivation has been reported for both direct techniques (If $\mathrm{PEVCD}^{21}$ and $\mathrm{rf} \mathrm{PECVD}^{7,8}$ ) as well as for remote microwave techniques. ${ }^{16,22,23}$

Apart from the performance of the $a-\mathrm{SiN}_{x}: \mathrm{H}$, a general major economical concern is the processing time of the material, which is directly related to throughput and production costs. The deposition rate of $a-\mathrm{SiN}_{x}: \mathrm{H}$ is therefore a key issue in the application of the material in large-scale solar cell production. ${ }^{2}$ For the above-mentioned techniques, deposition rates have been obtained of $0.05-0.15 \mathrm{~nm} / \mathrm{s}$ for If PECVD in a $\mathrm{NH}_{3} / \mathrm{SiH}_{4}$ plasma, ${ }^{19} 0.2 \mathrm{~nm} / \mathrm{s}$ for rf PECVD in a $\mathrm{NH}_{3} / \mathrm{SiH}_{4}$ mixture, ${ }^{7} 0.25-0.5 \mathrm{~nm} / \mathrm{s}$ for $\mathrm{rf}$ PECVD in a $\mathrm{N}_{2} / \mathrm{SiH}_{4}$ plasma, and $\sim 1 \mathrm{~nm} / \mathrm{s}$ for RPECVD with $\mathrm{NH}_{3} / \mathrm{SiH}_{4}$ mixtures. ${ }^{13}$

Increasing the deposition rate well over $1 \mathrm{~nm} / \mathrm{s}$ has been the motivation for work described in this article. The feasibility of high-rate deposition of $a-\operatorname{SiN}_{x}: \mathrm{H}$ with a simultaneous fulfillment of the requirements on the film properties with respect to AR performance and surface and bulk passivation will be considered using the so-called "expanding thermal plasma" (ETP) method. ${ }^{24}$ This is a remote plasma deposition technique which has proven to be capable of depositing good quality $a-\mathrm{C}: \mathrm{H}$ and $a-\mathrm{Si}: \mathrm{H}$ films (for thin film $a$-Si:H solar cells) at rates of $60 \mathrm{~nm} / \mathrm{s}$ (Ref. 25) and 10 $\mathrm{nm} / \mathrm{s},{ }^{26}$ respectively. These deposition rates are much higher than those obtained by conventional PECVD techniques. The high deposition rates that can be obtained with the ETP technique are directly related to the high production rate of reactive species, which is due to very efficient plasma creation in a high pressure plasma source (a cascaded arc thermal plasma source). Other advantages of the technique are the absence of (energetic) ion bombardment and the fact that $\mathrm{N}_{2}$ can simply be used instead of $\mathrm{NH}_{3}$. The latter is possible because the "strongly bonded" $\mathrm{N}_{2}$ is easily dissociated in the thermal plasma source. Furthermore, the technique can easily be used in-line, either as a single wafer technique or as a line-source (comprising several cascaded arc plasma sources) for multiple wafer processing.

This article is organized as follows: in Sec. II the experimental setup is described as well as the film analysis techniques used. Section III deals with the results of the work in which first the deposition rate, structural and compositional film properties, and film homogeneity will be treated (Sec. III A). This is followed by investigations on the AR working of the material (Sec. IIIB) and surface passivation (Sec. 


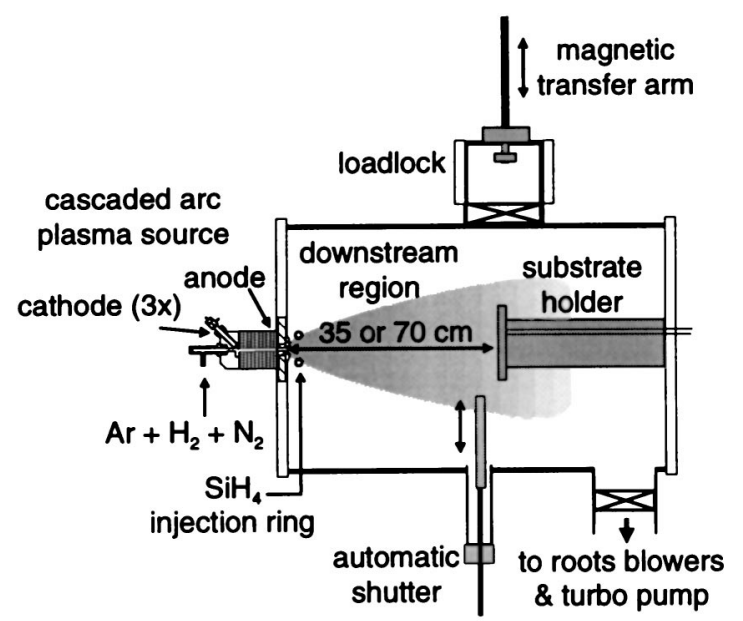

FIG. 1. Expanding thermal plasma (ETP) setup for $a-\mathrm{SiN}_{x}: \mathrm{H}$ deposition at high rates. The distance between plasma source and substrate holder is either 35 or $70 \mathrm{~cm}$. The figure is not to scale.

III C) and bulk passivation (Sec. III D) performance. The AR performance and surface passivation have been investigated on mono-Si wafers and cells and are compared by reference measurements on $a-\mathrm{SiN}_{x}: \mathrm{H}$ films deposited at the Institut für Solarenergieforschung Hameln-Emmerthal (ISFH) in Germany. The bulk passivation experiments has been investigated for industrial mc-Si solar cells that were processed by the Energy Research Center of the Netherlands (ECN Solar Energy).

\section{EXPERIMENT}

\section{A. Experimental setup}

The ETP setup is schematically illustrated in Fig. 1. It consists of a dc operated high-pressure cascaded arc plasma source $^{27}$ and a low-pressure deposition reactor. The cascaded arc has three cathodes and an anode plate with nozzle and these are separated by a stack of ten plates with a central aperture of $4 \mathrm{~mm}$ in diameter (plasma channel). The "cascaded" plates are electrically insulated by boron nitride and polyvinilchloride spacers. All other parts are made from copper, except the cathode tips which are made from tungsten with 2\% lanthanum. All copper parts are water cooled and o-rings are used for vacuum sealing. The cascaded arc is
TABLE I. Discharge parameters of the ETP for $a-\mathrm{SiN}_{x}: \mathrm{H}$ deposition at high deposition rates.

\begin{tabular}{cc}
\hline \hline Arc current & $45 \mathrm{~A}$ \\
Arc voltage & $180-210 \mathrm{~V}$ \\
Arc pressure & $40 \mathrm{kPa}$ \\
Ar flow & $55 \mathrm{sccs}$ \\
$\mathrm{N}_{2}$ flow & $10 \mathrm{sccs}$ \\
$\mathrm{H}_{2}$ flow & $0-5 \mathrm{sccs}$ \\
$\mathrm{SiH}_{4}$ flow & $1-15 \mathrm{sccs}$ \\
Downstream pressure & $16-21 \mathrm{~Pa}$ \\
Substrate temperature & $200-500^{\circ} \mathrm{C}$ \\
\hline \hline
\end{tabular}

operated at subatmospheric pressure with a nondepositing gas mixture of $\mathrm{Ar}, \mathrm{H}_{2}$, and $\mathrm{N}_{2}(99.999 \%$ purity) in the plasma channel. Through this channel a current is drawn between the three cathodes and the anode plate. Table I gives an overview of the gas flows [in sccs (standard $\mathrm{cm}^{3} / \mathrm{s}$ )] and other operating conditions. The plasma expands into the reactor chamber in which the pressure is kept at $\sim 20 \mathrm{~Pa}$ by means of a stack of two roots blowers and a fore-pump (total pumping capacity at the reactor is $\sim 1500 \mathrm{~m}^{3} / \mathrm{h}$ ). The pressure drop at the arc source outlet leads to a supersonic expansion of the plasma into the reactor followed by a stationary shock at $\sim 5 \mathrm{~cm}$ from the arc outlet. Behind the shock the expansion velocity is subsonic (typically $1000 \mathrm{~m} / \mathrm{s}$ ) and in this region precursor gases, such as $\mathrm{SiH}_{4}$ in the present case, are injected. This is done by means of a stainless steel injection ring having a diameter of $7.5 \mathrm{~cm}$ and containing ten holes with a diameter of $1 \mathrm{~mm}$ each. The $\mathrm{SiH}_{4}(99.995 \%$ purity) is dissociated by the reactive species emanating from the plasma source (mainly by ionic and atomic species, not by electrons ${ }^{28,29}$ ) leading to deposition precursors. The diameter of the deposition reactor is $50 \mathrm{~cm}$ while the length can either be 80 or $115 \mathrm{~cm}$ by using an additional extension flange. Overnight the reactor is pumped by a turbo molecular pump reaching a base-pressure of $<10^{-4} \mathrm{~Pa}$.

Depending on the length of the chamber, the substrate holder's position is either 35 or $70 \mathrm{~cm}$ from the arc outlet. The substrate holder, schematically illustrated in Fig. 2, is a modified version of the one described in Ref. 26. The holder consists of a yoke and aluminum or copper substrate plates that carry the substrates. A substrate plate can be inserted into the reactor without venting it by means of a loadlock

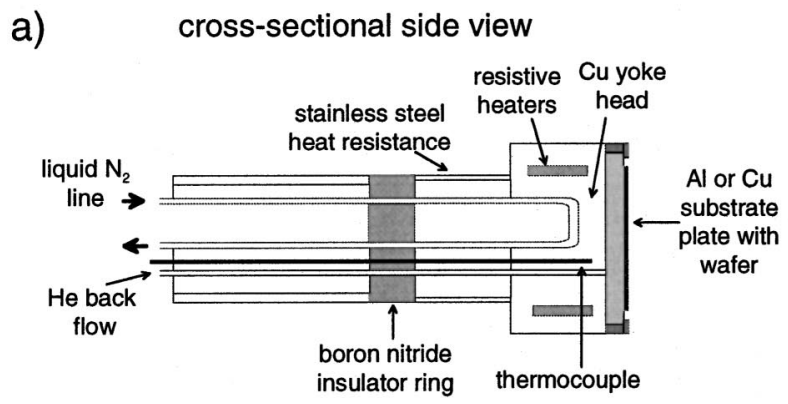

b) front view

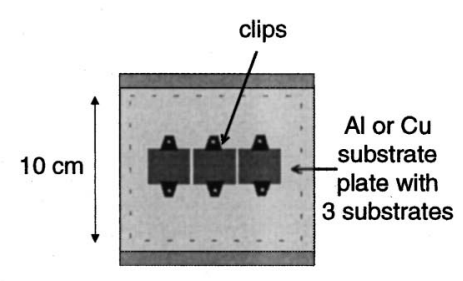

FIG. 2. Schematic of (a) cross-sectional side view and (b) front view of the substrate holder which can handle substrates/wafers up to $10 \times 10 \mathrm{~cm}^{2}$. The front view shows a substrate plate onto which three substrates of $2.5 \times 2.5 \mathrm{~cm}^{2}$ have been clamped. 


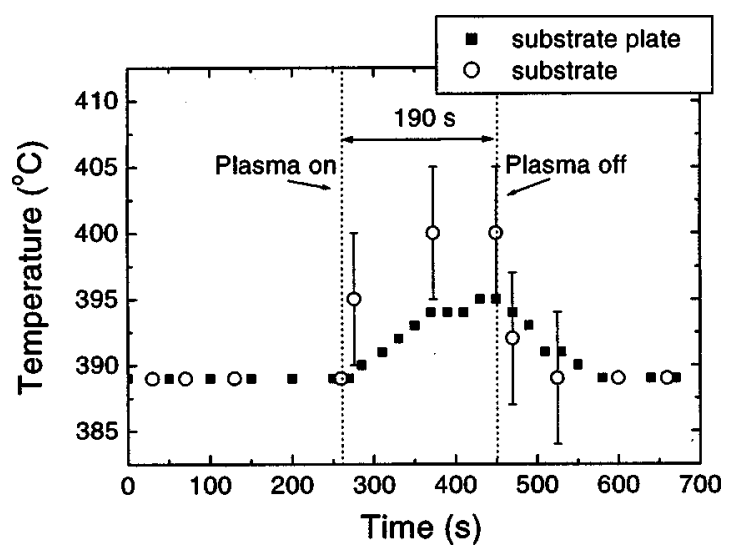

FIG. 3. Temperature of the substrate and substrate plate during plasma ignition. The set temperature of the yoke is $400{ }^{\circ} \mathrm{C}$. The plasma is ignited at $t$ $=260 \mathrm{~s}$ and shut off at $t=450 \mathrm{~s}$. The temperature of the substrate plate is determined by a thermocouple in the plate, the temperature of the substrate is determined by ellipsometry.

chamber and magnetic transporter. The substrate plate is thereafter mechanically clamped onto the yoke. A substrate plate can hold substrates (or cells) with a size up to 10 $\times 10 \mathrm{~cm}^{2}$. The plates are also often used to hold three substrates with a size of $2.5 \times 2.5 \mathrm{~cm}^{2}$ each. The substrates are mounted on the substrate plate by stainless steel clips.

The yoke has a copper head which can be resistively heated up to $500{ }^{\circ} \mathrm{C}$ (total heating power is $1 \mathrm{~kW}$ ) while temperature control is performed by a proportional-integralderivative (PID) controller. The copper head can also be cooled by means of a liquid $\mathrm{N}_{2}$ flow and the combination of cooling and heating is used for accurate and fast temperature control of the yoke at relatively low operating temperatures. ${ }^{25}$ The copper head of the yoke is thermally and electrically insulated from the rest of the yoke by means of a stainless steel heat resistance and ceramic (boron nitride) spacer, respectively. The electrical insulation makes the application of a dc or rf bias possible.

Because the ETP source usually delivers a heavy thermal load to the substrate holder, the thermal contact between yoke and substrate plate on one hand and the substrate plate and substrates on the other hand is optimized by a small helium backflow. ${ }^{25,30}$ The temperature control of the substrates has extensively been checked by means of a thermocouple in the substrate plate and by in situ ellipsometry on 0.5-mm-thick Corning 7059 glass substrates. The ellipsometry measurements enable real time monitoring of the substrate temperature after plasma ignition. A possible temperature change is observed by fringes in the ellipsometry data caused by thermal expansion of the substrate due to heating. In Fig. 3, the temperature increase is shown for a yoke temperature set at $400{ }^{\circ} \mathrm{C}$. The figure shows a relatively small temperature rise despite the heavy thermal load delivered by the plasma. ${ }^{25}$ Measurements at other yoke temperatures have revealed temperature changes of less than $15^{\circ} \mathrm{C}$ for all conditions.

The substrates are screened from the plasma during plasma startup and during gas admixture by means of a stain- less steel retractable shutter. This shutter is full automatically operated by means of a digital timer enabling precise control of the deposition time.

\section{B. Film and solar cell analysis}

The structural properties of the $a-\mathrm{SiN}_{x}: \mathrm{H}$ were analyzed on films approximately $300 \mathrm{~nm}$ thick that are deposited on $p$-type $c$-Si substrates $\left(500 \mu \mathrm{m}, 2.5 \times 2.5 \mathrm{~cm}^{2}, 10-20 \Omega \mathrm{cm}\right)$. The film analysis was performed by ex situ ellipsometry, infrared absorption spectroscopy, and elastic recoil detection (ERD). From the ellipsometry data the refractive index (at 2 $\mathrm{eV}$ ) and film thickness were determined. Information on the hydrogen content and on its bonding configurations was obtained by absorption spectroscopy using a Fourier transform infrared (FTIR) spectrometer (Bruker Vector 22). For this analysis, the peak positions $\omega_{0}$ and calibration constants $K$ for the hydrogen stretching modes as determined from a detailed study for different $a-\mathrm{SiN}_{x}: \mathrm{H}$ alloys by Bustarret et al. $^{31}$ were used: $\mathrm{HSi}-\mathrm{N}_{2} \mathrm{Si}$ and $\mathrm{H}_{2} \mathrm{Si}-\mathrm{NSi}$ at $\omega_{0}$ $=2140 \mathrm{~cm}^{-1} \quad\left(K=1.1 \times 10^{20} \mathrm{~cm}^{-2}\right), \quad \mathrm{H}_{2} \mathrm{Si}-\mathrm{N}_{2} \quad$ at $\omega_{0}$ $=2175 \mathrm{~cm}^{-1} \quad\left(K=4.0 \times 10^{20} \mathrm{~cm}^{-2}\right), \quad \mathrm{HSi}-\mathrm{N}_{3}$ at $\omega_{0}$ $=2220 \mathrm{~cm}^{-1} \quad\left(K=2.0 \times 10^{20} \mathrm{~cm}^{-2}\right), \quad \mathrm{NH} \quad$ at $\omega_{0}$ $=3340 \mathrm{~cm}^{-1} \quad\left(K=1.2 \times 10^{20} \mathrm{~cm}^{-2}\right), \quad \mathrm{NH}_{2} \quad$ at $\omega_{0}$ $=3450 \mathrm{~cm}^{-1}\left(K=5 \times 10^{20} \mathrm{~cm}^{-2}\right)$. Information on the N, Si, and $\mathrm{H}$ atomic densities in the films was obtained from ERD measurements performed at the Utrecht University using a $54 \mathrm{MeV}^{65} \mathrm{Cu}^{8+}$ beam. ${ }^{32}$

The AR performance of the $a-\mathrm{SiN}_{x}: \mathrm{H}$ was investigated for monocrystalline $0.5 \Omega \mathrm{cm}$ float zone $\mathrm{Si} p / n^{+}$solar cells with a $100 \Omega$ /sq emitter. The contacts were evaporated and are of $\mathrm{Al}$ on the back and of $\mathrm{Ti} / \mathrm{Pd} / \mathrm{Ag}$ on the front. The cells were fabricated from $300-\mu \mathrm{m}$-thick $1.5 \Omega \mathrm{cm}$ float zone $\mathrm{Si}$ substrates and have a size of $2.0 \times 2.0 \mathrm{~cm}^{2}$. Standard current-voltage measurements under 1.5 AM sun with 100 $\mathrm{mW} / \mathrm{cm}^{2}$ were applied to investigate the solar cell performance.

Surface passivation induced by the $a-\mathrm{SiN}_{x}: \mathrm{H}$ was examined on float zone $p$-type $c$-Si $\left(300 \mu \mathrm{m}, 2.5 \times 2.5 \mathrm{~cm}^{2}\right)$ with a low resistivity of $1.5 \Omega \mathrm{cm}$. Also some substrates with phosphorous diffusion on both sides (sheet resistance $100 \Omega / s q$ ) were used for some experiments. All substrates were cleaned with a standard RCA-clean followed by a HF dip (2\%, $30 \mathrm{~s})$ and were subsequently deposited with $a-\mathrm{SiN}_{x}: \mathrm{H}$ at both sides. Information on the effective surface recombination velocity (SRV) was deduced from effective minority-carrier lifetime measurements by means of the microwave-detected photoconductance decay (MW-PCD) under $50 \mathrm{~mW} / \mathrm{cm}^{2}$ bias illumination. ${ }^{33}$ Depending on the surface passivation quality this yielded a bulk charge injection level in the range of $10^{13}-10^{15} \mathrm{~cm}^{-3}$. More details about this analysis and the determination of the effective surface recombination velocity can be found in Refs. 4 and 13.

Bulk passivation experiments were carried out together with ECN Solar Energy on industrial Baysix mc-Si (Bayer Solar $\mathrm{GmbH}$ ) solar cells with a size of $10 \times 10 \mathrm{~cm}^{2}$ and a thickness of $\sim 330 \mu \mathrm{m}$. These cells have a diffused emitter with a sheet resistance of $50 \Omega / \mathrm{sq}$. After deposition, the met- 
TABLE II. Refractive index, deposition rate, film atomic concentrations of $\mathrm{H}, \mathrm{Si}$, and $\mathrm{N}$, mass density and the hydrogen bonding configurations for the $a-\mathrm{SiN}_{x}: \mathrm{H}$ films studied. The inaccuracy in the atomic concentrations is less than $5 \%$.

\begin{tabular}{|c|c|c|c|c|c|c|c|c|c|c|c|c|}
\hline \multirow{2}{*}{$\begin{array}{l}\mathrm{SiH}_{4} \\
\text { flow } \\
\text { (sces) }\end{array}$} & \multirow{2}{*}{$\begin{array}{c}\mathrm{H}_{2} \\
\text { flow } \\
\text { (sccs) }\end{array}$} & \multirow{2}{*}{$\begin{array}{c}\text { Substrate } \\
\text { temp. } \\
\left({ }^{\circ} \mathrm{C}\right)\end{array}$} & \multirow{2}{*}{$\begin{array}{l}\text { Refractive } \\
\text { index }\end{array}$} & \multirow{2}{*}{$\begin{array}{l}\text { Deposition } \\
\text { rate } \\
(\mathrm{nm} / \mathrm{s})\end{array}$} & \multicolumn{2}{|l|}{$[\mathrm{H}]$} & \multicolumn{2}{|c|}{$[\mathrm{Si}]$} & \multicolumn{2}{|l|}{$[\mathrm{N}]$} & \multirow{2}{*}{$\begin{array}{c}\text { Mass } \\
\text { density } \\
\left(\mathrm{g} / \mathrm{cm}^{3}\right)\end{array}$} & \multirow{2}{*}{$\begin{array}{l}\mathrm{H} \text { bonding } \\
\text { type }\end{array}$} \\
\hline & & & & & $\left(10^{22} \mathrm{~cm}^{-3}\right)$ & (at. \%) & $\left(10^{22} \mathrm{~cm}^{-3}\right)$ & (at. \%) & $\left(10^{22} \mathrm{~cm}^{-3}\right)$ & (at. \%) & & \\
\hline 15 & 5 & 400 & 2.7 & 35.5 & 1.26 & 18.4 & 3.92 & 57.3 & 1.67 & 24.3 & 2.24 & $\sim 100 \% \mathrm{SiH}$ \\
\hline 8 & 5 & 400 & 2.3 & 19.4 & 1.23 & 17.4 & 3.42 & 48.4 & 2.41 & 34.2 & 2.19 & $\sim 100 \% \mathrm{SiH}$ \\
\hline 4 & 5 & 400 & 2.2 & 13.2 & 1.20 & 16.4 & 2.83 & 38.6 & 3.30 & 45.0 & 2.12 & $\begin{array}{l}\sim 81 \% \mathrm{SiH} \\
\sim 19 \% \mathrm{NH}\end{array}$ \\
\hline 2 & 5 & 400 & 2.1 & 6.2 & 2.18 & 15.4 & 5.27 & 37.3 & 6.68 & 47.3 & 4.06 & $\sim 100 \% \mathrm{NH}_{x}^{\mathrm{a}}$ \\
\hline 1 & 5 & 400 & 2.0 & 4.0 & 1.87 & 16.6 & 4.32 & 38.2 & 5.10 & 45.2 & 3.24 & $\sim 100 \% \mathrm{NH}_{x}^{\mathrm{a}}$ \\
\hline 8 & 5 & 200 & 2.0 & 21.4 & 1.37 & 17.3 & 3.93 & 49.6 & 2.63 & 33.2 & 2.47 & $\begin{array}{c}\sim 80 \% \mathrm{SiH} \\
\sim 12 \% \mathrm{SiH}_{2} \\
\sim 8 \% \mathrm{NH}\end{array}$ \\
\hline 8 & 5 & 300 & 2.2 & 20.4 & 1.68 & 20.9 & 3.88 & 48.2 & 2.49 & 30.9 & 2.42 & $\begin{array}{c}\sim 67 \% \mathrm{SiH} \\
\sim 29 \% \mathrm{SiH}_{2} \\
\sim 4 \% \mathrm{NH}\end{array}$ \\
\hline 8 & 5 & 500 & 2.4 & 19.1 & 0.90 & 12.6 & 3.58 & 49.9 & 2.69 & 37.5 & 2.32 & $\sim 100 \% \mathrm{SiH}$ \\
\hline 8 & 3 & 400 & 2.3 & 20.4 & 1.28 & 18.3 & 3.26 & 46.4 & 2.48 & 35.3 & 2.12 & $\sim 100 \% \mathrm{SiH}$ \\
\hline 8 & 1 & 400 & 2.4 & 25.3 & 1.19 & 16.3 & 3.43 & 46.9 & 2.70 & 36.9 & 2.25 & $\begin{array}{l}\sim 90 \% \mathrm{SiH} \\
\sim 10 \% \mathrm{NH}\end{array}$ \\
\hline 8 & 0 & 400 & 2.5 & 31.8 & 1.39 & 17.3 & 3.74 & 46.5 & 2.91 & 36.2 & 2.45 & $\begin{array}{l}\sim 90 \% \mathrm{SiH} \\
\sim 10 \% \mathrm{NH}\end{array}$ \\
\hline
\end{tabular}

${ }^{a}$ A quantification of the $\mathrm{NH}_{x}$ bondings in terms of $\mathrm{NH}$ and $\mathrm{NH}_{2}$ has not been possible.

allization was screen-printed on the $a-\mathrm{SiN}_{x}: \mathrm{H}$ AR coating and subsequently fired through the coating in an infrared lamp heated belt surface. The cell performance was measured with the class $A$ solar simulator at ECN Solar Energy. Spectral response measurements in combination with reflectance measurements were used to calculate the internal quantum efficiency IQE of the cells.

\section{RESULTS AND DISCUSSION}

\section{A. Structural and compositional film properties}

To obtain insight into the film properties that can be obtained with the ETP technique, the structural and compositional properties of the high-rate deposited $a-\mathrm{SiN}_{x}: \mathrm{H}$ films were analyzed for different plasma operating conditions. Three different parameter studies were performed starting from a "standard condition" (i.e., $10 \operatorname{sccs} \mathrm{N}_{2}, 5 \operatorname{sccs} \mathrm{H}_{2}, 8$ sccs $\mathrm{SiH}_{4}$ and a substrate temperature of $400{ }^{\circ} \mathrm{C}$ as decided on from some first experiments): $\mathrm{a} \mathrm{SiH}_{4}$ flow variation, a $\mathrm{H}_{2}$ flow variation, and a substrate temperature variation. The $\mathrm{N}_{2}$ flow was kept constant at 10 sccs for all experiments. The distance between cascaded arc plasma source and substrate holder was $35 \mathrm{~cm}$ for these experiments. The results of these measurements are summarized in Table II. The refractive index (at $2 \mathrm{eV}$ ) and deposition rate, which ranges from 4 to 35 $\mathrm{nm} / \mathrm{s}$, were determined by ex situ ellipsometry. The deposition rate is in very good agreement with the deposition rate obtained from interference fringes in the FTIR transmission data. The atomic concentrations of $\mathrm{H}, \mathrm{Si}$, and $\mathrm{N}$ were determined from the ERD analysis and these concentrations were used for the calculation of the mass density of the films. Insight in the $\mathrm{H}$ bonding configuration was obtained by the FTIR analysis using the calibration constants from Bustarret et $a l .{ }^{31}$ given in Sec. II B. The FTIR data will be discussed in more detail below, but it can already be mentioned that the agreement between the $\mathrm{H}$ concentration as determined by FTIR and ERD is within 25\%, except for two cases where the samples contain a significant amount of $\mathrm{NH}_{2}$ (absorption at $\sim 3450 \mathrm{~cm}^{-1}$ ). In these low-substrate temperature cases, the $\mathrm{H}$ content determined from the FTIR data appears to be too high. Such a difference is possibly due to the experimental accuracy and the dependence of the calibration constants on the overall film properties, as also suggested by the discrepancies in calibration constants reported in the literature. ${ }^{31,34,35}$ Furthermore, some weak $\mathrm{NH}_{x}$ absorption peaks observed for conditions with a low $\mathrm{SiH}_{4}$ flow could not be attributed to a certain $\mathrm{H}$ bonding configuration unambiguously. This makes the subdivision of the $\mathrm{NH}_{x}$ bonds in terms of $\mathrm{NH}$ and $\mathrm{NH}_{2}$ impossible for the data presented.

The data in Table II reveal that the $\mathrm{SiH}_{4}$ flow is a very important parameter for the film properties. In Fig. 4, the deposition rate, refractive index, and N/Si ratio are displayed as a function of the $\mathrm{SiH}_{4}$ flow. The deposition rate and particularly the $\mathrm{Si}$ growth flux (i.e., product of deposition rate and $\mathrm{Si}$ atomic film density) shows a linear increase with $\mathrm{SiH}_{4}$ flow. The refractive index of the films is also strongly dependent on the $\mathrm{SiH}_{4}$ flow. For both the 300 and $400{ }^{\circ} \mathrm{C}$ samples, the refractive index shows the same increasing trend with $\mathrm{SiH}_{4}$ flow, while the refractive index is somewhat higher for the $400{ }^{\circ} \mathrm{C}$ samples as will be discussed below. The data show that the refractive index can be tuned in the range of $\sim 1.8-2.7$ by changing the $\mathrm{SiH}_{4}$ flow. The ERD data in Fig. 4(c) reveal that the refractive index is directly coupled with the N/Si ratio in the film. The refractive index increases with decreasing N/Si ratio showing that the films can be changed from N-rich to Si-rich by increasing the $\mathrm{SiH}_{4}$ flow for constant $\mathrm{N}_{2}$ admixture in the arc. Moreover, the general trend is 


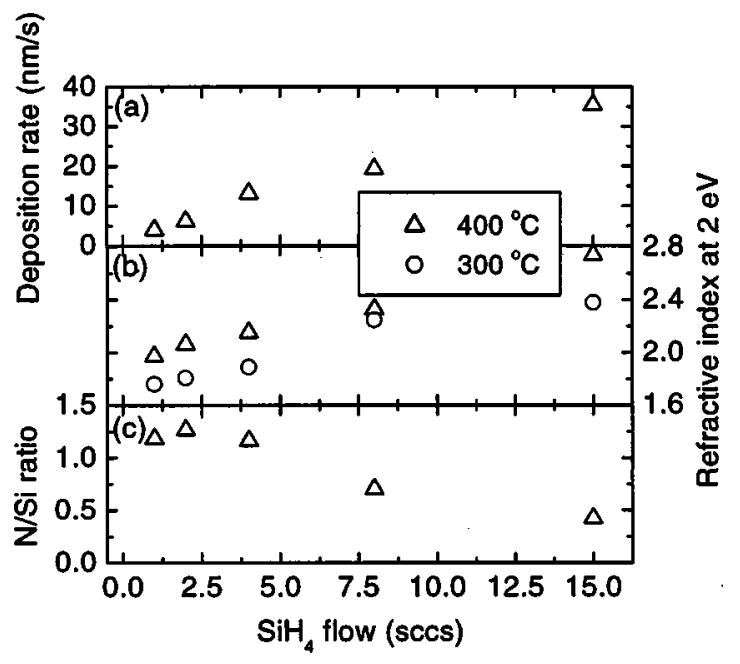

FIG. 4. (a) Deposition rate, (b) refractive index, and (c) N/Si ratio as a function of $\mathrm{SiH}_{4}$ flow for films deposited at substrate temperatures of 300 and $400{ }^{\circ} \mathrm{C}$ and with a $\mathrm{H}_{2}$ flow of 5 sccs.

observed that the film density increases with the $\mathrm{N} / \mathrm{Si}$ ratio. $^{34,36}$

The hydrogen content of the films is roughly $15 \%-18 \%$ and shows no clear dependence on the $\mathrm{SiH}_{4}$ flow. The bonding configuration of the hydrogen is however strongly depen-
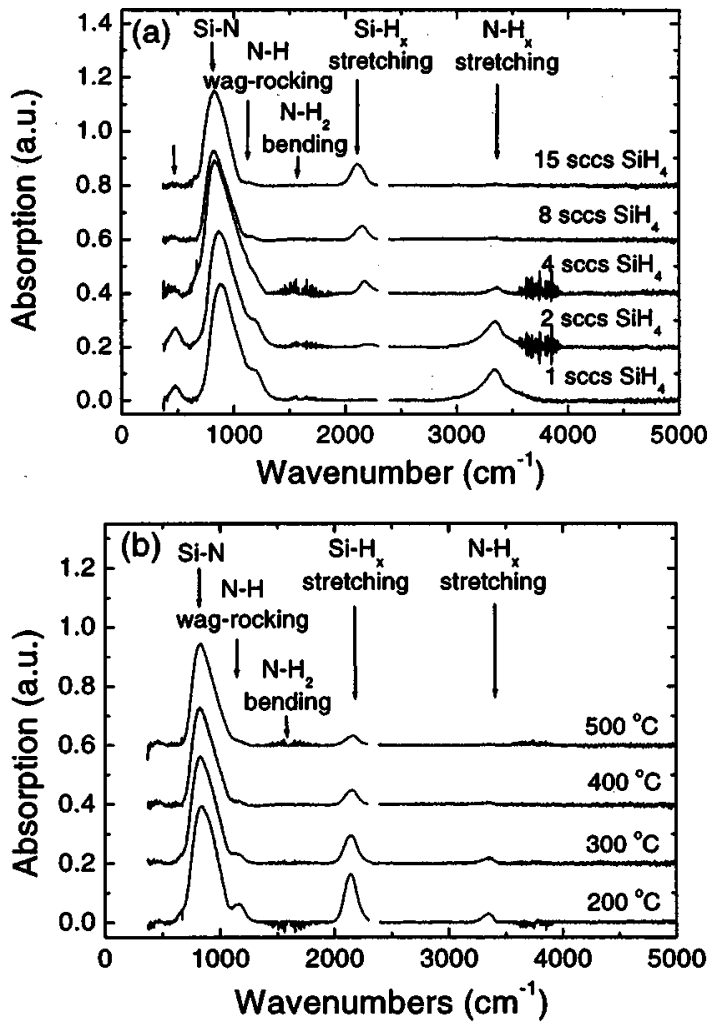

FIG. 5. Infrared spectra (a) for different $\mathrm{SiH}_{4}$ flows with a substrate temperature of $400{ }^{\circ} \mathrm{C}$ and $\mathrm{H}_{2}$ flow of 5 sccs and (b) for different substrate temperatures with a $\mathrm{SiH}_{4}$ flow of 8 sccs and $\mathrm{H}_{2}$ flow of 5 sccs. The absorption peak around $2350 \mathrm{~cm}^{-1}$ caused by ambient $\mathrm{CO}_{2}$ during the measurements has been removed. Furthermore, some spectra show influence of absorptions by ambient $\mathrm{H}_{2} \mathrm{O}$ around 1600 and $3750 \mathrm{~cm}^{-1}$.

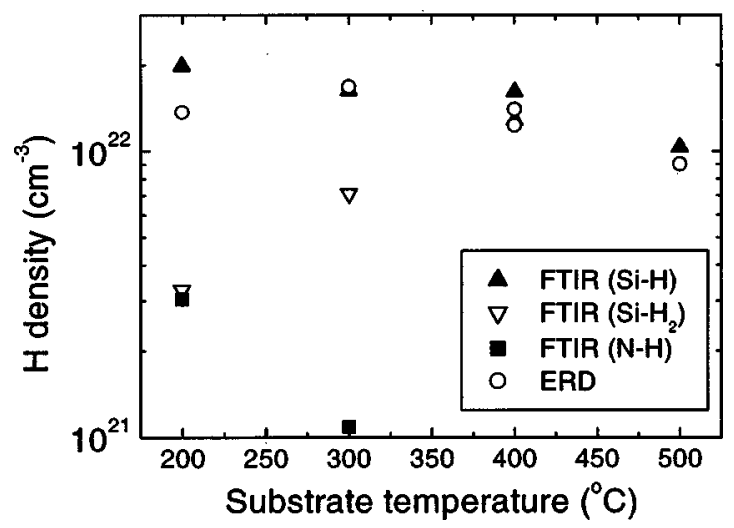

FIG. 6. Atomic hydrogen density as determined from ERD analysis and from FTIR absorption spectroscopy ([SiH], $\left.\left[\mathrm{SiH}_{2}\right],[\mathrm{NH}]\right)$ for different substrate temperatures. The $\mathrm{H}_{2}$ and $\mathrm{SiH}_{4}$ flow are 5 and 8 sccs, respectively.

dent on the $\mathrm{SiH}_{4}$ flow as indicated by the infrared vibrational spectra in Fig. 5(a). Concerning the hydrogen stretching modes, at low $\mathrm{SiH}_{4}$ flows, there are only absorptions due to $\mathrm{NH}$ at $3340 \mathrm{~cm}^{-1}$ and $\mathrm{NH}_{2}$ at $\sim 3450 \mathrm{~cm}^{-1}$ while the origin of the shoulder at $\sim 3230 \mathrm{~cm}^{-1}$ is unclear but appears to be related to $\mathrm{NH}_{x}$ as well. Absorptions are also present around 1540 and $1170 \mathrm{~cm}^{-1}$ due to $\mathrm{NH}_{2}$ bending and $\mathrm{NH}$ wagrocking modes, respectively. ${ }^{31}$ Furthermore, there appears to be an absorption at $490 \mathrm{~cm}^{-1}$ at low $\mathrm{SiH}_{4}$ flows, which has been attributed to $\mathrm{NSi}_{3}$ symmetric stretching ${ }^{37,38}$ but also to distorted $\mathrm{Si}-\mathrm{Si}$ cluster vibrations. ${ }^{39} \mathrm{Si}-\mathrm{N}$ stretching modes are also directly related to the large absorption peak(s) ranging from 700 to $1050 \mathrm{~cm}^{-1}$. In the literature, ${ }^{39-41}$ there is however still controversy about the exact origin of these absorptions and therefore these will not be considered in this article. When going to high $\mathrm{SiH}_{4}$ flows on the other hand, the $\mathrm{NH}_{x}$ absorptions disappear almost completely and only $\mathrm{H}$ bonded as $\mathrm{SiH}$ is observed. The center of the $\mathrm{SiH}$ stretching absorption peaks shifts to lower wave numbers when going to more Si-rich material. This fact is well known ${ }^{31}$ and can be explained by the decrease in $\mathrm{N}$ backbonds for the $\mathrm{SiH}_{x}$ hydrides. It can therefore be concluded that there is a transition from an almost pure $\mathrm{NH}_{x}$ bonding configuration for low $\mathrm{SiH}_{4}$ flows to an almost pure $\mathrm{SiH}_{x}$ bonding configuration for higher $\mathrm{SiH}_{4}$ flows. This is in agreement with the transition from N-rich to Si-rich $a-\mathrm{SiN}_{x}: \mathrm{H}$ as also observed in other studies. ${ }^{31,39}$ In summary, by changing the $\mathrm{SiH}_{4}$ flow the refractive index and atomic composition can be fully tuned from N-rich to Si-rich. On basis of these and other data, ${ }^{29}$ it is also expected that this tuning can be done by changing the $\mathrm{N}_{2}$ flow for constant $\mathrm{SiH}_{4}$ flow.

The influence of the substrate temperature was investigated in more detail for Si-rich samples deposited with 8 sccs $\mathrm{SiH}_{4}$. In Table II, it can be seen that the deposition rate slightly decreases with increasing substrate temperature whereas the refractive index increases. This is not simply due to a densification of the material as follows from the $\mathrm{Si}$ and $\mathrm{N}$ density as well as from the mass density. The increase of the refractive index is presumably caused by the decreasing $\mathrm{H}$ density in the film as shown in Fig. 6. This figure also 
shows the bonding configuration of the hydrogen based on the infrared data in Fig. 5(b). In Fig. 5(b), the spectra at temperatures of 200 and $300{ }^{\circ} \mathrm{C}$ show the $\mathrm{NH}$ wag-rocking mode and stretching mode at 1175 and $3340 \mathrm{~cm}^{-1}$, respectively. For higher substrate temperatures no significant amount of hydrogen bonded to nitrogen can be observed showing that substrate temperatures above $300{ }^{\circ} \mathrm{C}$ are necessary to avoid $\mathrm{NH}$ bonded hydrogen, even for these "Si-rich conditions." At lower substrate temperatures, the $\mathrm{SiH}_{x}$ stretching modes show also a shoulder at higher wave numbers which is most presumably due to $\mathrm{SiH}_{2}$ bonded hydrogen. Furthermore, it is interesting that no absorption around $490 \mathrm{~cm}^{-1}$ appears for the low temperature films with a considerable absorption by $\mathrm{NH}$. This is different from the trend observed for the films in Fig. 5(a).

All experiments discussed so far were performed with 5 sccs of $\mathrm{H}_{2}$ admixed in the cascaded arc. The decision to work with $\mathrm{H}_{2}$ is based on previous experience with the deposition of $a-\mathrm{Si}: \mathrm{H}$. Experiments with this material revealed that $\mathrm{H}_{2}$ admixture in the arc is crucial for obtaining solar grade quality $a-\mathrm{Si}: \mathrm{H}$ for thin film solar cells with the ETP technique. ${ }^{26,42}$ The beneficial working of the $\mathrm{H}_{2}$ admixture could be attributed to a lower ion flow from the cascaded arc making ion-induced dissociation of $\mathrm{SiH}_{4}$ less important. ${ }^{28,42}$ In order to investigate whether the use of $\mathrm{H}_{2}$ is also important for the deposition of $a-\mathrm{SiN}_{x}: \mathrm{H}$ the structural properties were analyzed for $\mathrm{H}_{2}$ flows varying from 5 sccs down to 0 sccs. The $\mathrm{SiH}_{4}$ flow and substrate temperature were kept constant at 8 sccs and $400{ }^{\circ} \mathrm{C}$, respectively. As shown in Table II, lowering the $\mathrm{H}_{2}$ flow down to zero, yields a slight increase in refractive index and a $50 \%$ increase in deposition rate. Furthermore, the atomic densities of $\mathrm{Si}, \mathrm{N}$, and $\mathrm{H}$ are higher for the condition with 0 sccs $\mathrm{H}_{2}$ than for the conditions with $\mathrm{H}_{2}$ admixture. The N/Si ratio is in the range of $0.7-0.8$ and increases slightly when going to $0 \mathrm{sccs}_{2}$ admixture. The infrared spectra for the different $\mathrm{H}_{2}$ flows (data not shown) show no significant changes with $\mathrm{H}_{2}$ flows except for the fact that the films at 0 and $1 \operatorname{sccs~}_{2}$ contain a considerable amount of $\mathrm{NH}$ bonded hydrogen (about 10\%). This is in agreement with the fact that these films have also a relatively higher $\mathrm{N} / \mathrm{Si}$ ratio. In summary, some changes of the film properties with $\mathrm{H}_{2}$ flow are observed, however these changes are not as drastic as for the deposition of $a-\mathrm{Si}: \mathrm{H}$. On the basis of measurements and expectations on the plasma chemistry and film growth mechanism ${ }^{29,43}$ it has been decided to work with 5 sccs $\mathrm{H}_{2}$ admixture throughout the following experiments.

As mentioned, the experiments discussed so far were carried out with a plasma source-substrate distance of $35 \mathrm{~cm}$. This yields a relatively poor homogeneity of the film thickness and the aforementioned analysis of the film properties was therefore done on substrates with a size of only 2.5 $\times 2.5 \mathrm{~cm}^{2}$. However, for the application of the $a-\mathrm{SiN}_{x}: \mathrm{H}$ on solar cells, the deposition of homogeneous films on larger areas is required. For this reason, experiments on the film homogeneity were carried out with a reactor chamber having an extended plasma source-substrate distance of $70 \mathrm{~cm}$. The
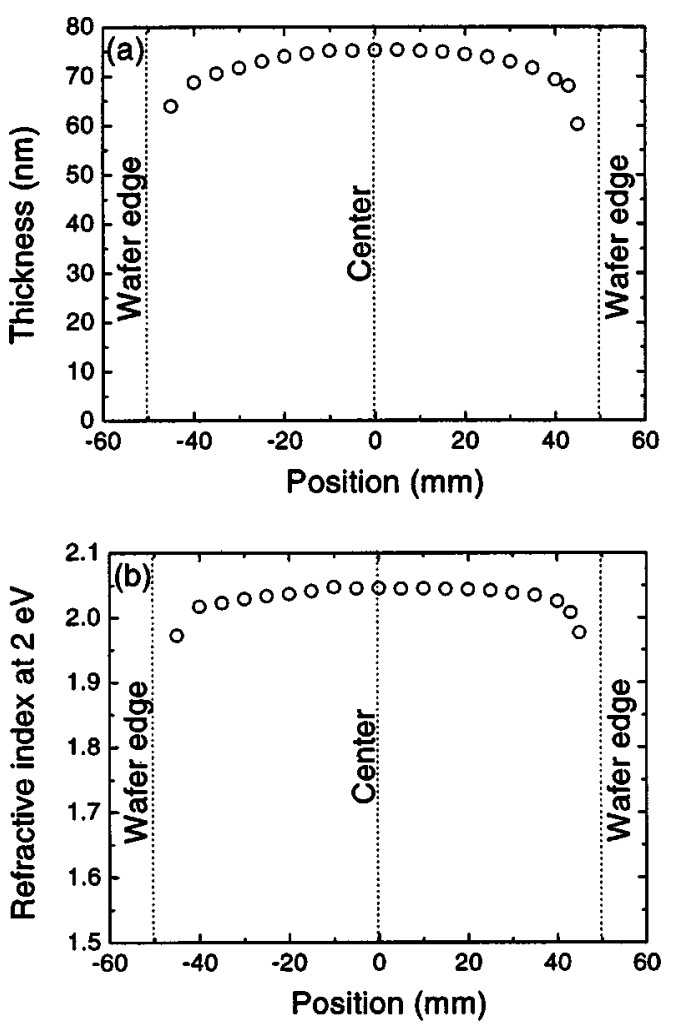

FIG. 7. Homogeneity of the (a) thickness and (b) refractive index as examined by ellipsometry for an $a-\mathrm{SiN}_{x}: \mathrm{H}$ film deposited on a monocrystalline silicon wafer with a diameter of $10 \mathrm{~cm}$. The film has been deposited with a plasma source-substrate distance of $70 \mathrm{~cm}$ with the conditions: $4 \mathrm{sccs} \mathrm{SiH}_{4}$, $5 \operatorname{sccs} \mathrm{H}_{2}$, and substrate temperature of $400{ }^{\circ} \mathrm{C}$.

$a-\mathrm{SiN}_{x}: \mathrm{H}$ was deposited onto monocrystalline $\mathrm{Si}$ wafers with a diameter of $10 \mathrm{~cm}$ and the homogeneity of both the thickness and refractive index was tested by ex situ ellipsometry. Figure 7 shows the results for the deposition condition with $4 \operatorname{sccs} \mathrm{SiH}_{4}$ and the other parameters standard (see Table I, 5 sccs $\mathrm{H}_{2}$ and substrate temperature of $400^{\circ} \mathrm{C}$ ). Figure 7(a) shows a thickness homogeneity of $<8 \%$ within wafer which is considerable better than for a plasma sourcesubstrate distance of $35 \mathrm{~cm}$. As expected, the improvement has taken place at the cost of deposition rate which is now 9 $\mathrm{nm} / \mathrm{s}$ for this condition instead of $13 \mathrm{~nm} / \mathrm{s}$. The homogeneity of the refractive index, which is $<2 \%$ within wafer [Fig. 7(b)], is much better than the thickness homogeneity. The refractive index has also slightly been affected by increasing the plasma source-substrate distance: $n=2.05$ instead of $n$ $=2.16$. Overall, these results on the homogeneity are reasonable and can certainly be used as a starting point. Apart from increasing the plasma source-substrate distance, for future optimization of the homogeneity the utilization of multiple cascaded arc plasma sources yields an interesting opportunity. Multiple cascaded arcs can either be implemented in a single-wafer deposition reactor or as a line-source in a reactor with moving wafers on a conveyor belt.

\section{B. Antireflection coating performance}

The reduction of the reflection of light at the solar cells' surface is the most essential feature of an $a-\mathrm{SiN}_{x}: \mathrm{H} \mathrm{AR}$ 
TABLE III. Solar cell parameters $\left(100 \mathrm{~mW} / \mathrm{cm}^{2}\right.$ illumination, AM1.5 spectrum) before and after deposition of the $a$-SiN $x$ :H AR coating with the ETP technique. The data for every $\mathrm{SiH}_{4}$ flow is an average value over two cells deposited under identical conditions. Reference measurements with $a$-SiN ${ }_{x}: \mathrm{H}$ deposited with a rf parallel plate capacitively coupled plasma at ISFH are also given.

\begin{tabular}{|c|c|c|c|c|c|c|c|c|c|c|}
\hline & \multicolumn{2}{|c|}{ Film parameters: } & \multicolumn{4}{|c|}{ Before antireflection coating: } & \multicolumn{4}{|c|}{ After antireflection coating: } \\
\hline & $\begin{array}{l}\text { Refractive } \\
\text { index }\end{array}$ & $\begin{array}{c}\text { Thickness } \\
(\mathrm{nm})\end{array}$ & $\begin{array}{c}V_{\mathrm{oc}} \\
(\mathrm{mV})\end{array}$ & $\begin{array}{c}J_{\mathrm{sc}} \\
\left(\mathrm{mA} / \mathrm{cm}^{2}\right)\end{array}$ & $\mathrm{FF}$ & $\begin{array}{c}\eta \\
(\%)\end{array}$ & $\begin{array}{c}V_{\mathrm{oc}} \\
(\mathrm{mV})\end{array}$ & $\begin{array}{c}J_{\mathrm{sc}} \\
\left(\mathrm{mA} / \mathrm{cm}^{2}\right)\end{array}$ & $\mathrm{FF}$ & $\begin{array}{c}\eta \\
(\%)\end{array}$ \\
\hline \multirow[t]{5}{*}{ ETP } & 1.8 & 93 & 617 & 25.8 & 0.81 & 12.8 & 627 & 34.8 & 0.81 & 17.5 \\
\hline & 1.9 & 84 & 615 & 25.7 & 0.81 & 12.7 & 628 & 35.0 & 0.81 & 17.7 \\
\hline & 1.9 & 81 & 617 & 25.8 & 0.80 & 12.8 & 632 & 35.4 & 0.81 & 18.1 \\
\hline & 2.0 & 75 & 615 & 25.3 & 0.80 & 12.5 & 631 & 34.6 & 0.80 & 17.5 \\
\hline & & & & Average ETP: & & 12.7 & & & & $\mathbf{1 7 . 7}$ \\
\hline \multirow[t]{4}{*}{ ISFH } & 1.9 & 79 & 615 & 25.3 & 0.81 & 12.6 & 635 & 35.3 & 0.81 & 18.2 \\
\hline & 2.0 & 75 & 615 & 26.2 & 0.79 & 12.8 & 639 & 35.5 & 0.81 & 18.4 \\
\hline & 2.1 & 69 & 614 & 25.2 & 0.82 & 12.7 & 636 & 34.9 & 0.81 & 18.1 \\
\hline & & & & Average ISFH: & & 12.7 & & & & 18.2 \\
\hline
\end{tabular}

coating because it can yield a gain in the solar cell's efficiency of several percents (absolute). To test the AR performance of the ETP $a-\mathrm{SiN}_{x}: \mathrm{H}$, a set of small area (2 $\left.\times 2 \mathrm{~cm}^{2}\right) \mathrm{p} / \mathrm{n}^{+}$solar cells with a $100 \Omega / \mathrm{sq}$ emitter were produced with evaporated metal contacts on front and back (see Sec. II B). The performance of these cells was tested and subsequently the cells were coated with the ETP $a-\operatorname{SiN}_{x}: \mathrm{H}$. The experiments were carried out with a plasma sourcesubstrate distance of $35 \mathrm{~cm}$ explaining the choice of the small area of the cells. During deposition, the substrate temperature was set at $400{ }^{\circ} \mathrm{C}$ while $5 \operatorname{sccs} \mathrm{H}_{2}, 10 \operatorname{sccs} \mathrm{N}_{2}$, and four different $\mathrm{SiH}_{4}$ flows were used. For comparison, three reference cells were produced with $a-\mathrm{SiN}_{x}: \mathrm{H}$ deposited at a substrate temperature $400{ }^{\circ} \mathrm{C}$ in a rf parallel plate reactor at ISFH. ${ }^{18}$ The conditions of these reference cells were chosen such that films with different values of the refractive index were obtained.

Table III shows the cell's parameters open circuit voltage $V_{\mathrm{oc}}$, short circuit current $I_{\mathrm{sc}}$, fill factor FF, and efficiency $\eta$ before and after the application of the $a-\mathrm{SiN}_{x}: \mathrm{H}$ as measured under standard test conditions. The parameters of the cells coated with ETP deposited $a-\mathrm{SiN}_{x}: \mathrm{H}$ are averaged over two separate cells processed for each of the four conditions.

All cells in Table III show a large gain in current due to the AR working of the $a-\operatorname{SiN}_{x}: \mathrm{H}$ films. For the cells coated with the ETP technique, the increase in current is not quite as big than for the reference cells coated at ISFH but the film parameters of the ETP deposited $a-\mathrm{SiN}_{x}: \mathrm{H}$ coatings are not as well optimized yet. Further optimization is certainly possible and therefore the somewhat lower increase in current does not present a fundamental problem. Furthermore, the increase in $V_{\mathrm{oc}}$, which can be caused by the increase in current as well as by surface passivation of the cell, is also not as large for the cells coated with the ETP as for the references. This seems mainly to be caused by the lower degree of surface passivation achieved with ETP $a-\mathrm{SiN}_{x}: \mathrm{H}$ (see Sec. III C). It is however clear from Table III that this leads only to a minor difference in cell efficiency. This difference would actually be even smaller on industrial-type solar cells, where a highly doped emitter is typically used to accommodate screen-printed front contacts. It can therefore be concluded that the ETP deposited $a-\mathrm{SiN}_{x}: \mathrm{H}$ can successfully be applied as a high-rate deposited AR coating.

\section{Surface passivation}

The results in the previous section suggest that the ETP deposited $a-\mathrm{SiN}_{x}: \mathrm{H}$ films on monocrystalline $\mathrm{Si}$ solar cells do not lead to a high degree of surface passivation. At the moment, a high degree of surface passivation is mainly important for the very high efficiency solar cells but surface passivation by $a-\mathrm{SiN}_{x}: \mathrm{H}$ will gain gradually more importance when solar cells become thinner in order to reduce material costs. To test the degree of surface passivation obtained by the ETP deposited $a-\operatorname{SiN}_{x}: \mathrm{H}$, lifetime experiments were performed: the effective lifetime of the minority charge carriers in high quality, $p$-type float zone monocrystalline $\mathrm{Si}$ substrates with a low resistivity of $1.5 \Omega \mathrm{cm}$ was measured after coating the substrates with $a-\mathrm{SiN}_{x}: \mathrm{H}$ at both sides. All depositions were performed with a $\mathrm{H}_{2}$ and $\mathrm{N}_{2}$ flow of 5 and 10 sccs, respectively, while the $\mathrm{SiH}_{4}$ flow was varied from 1 to 15 sccs. A substrate temperature of $300{ }^{\circ} \mathrm{C}$ was used for most depositions but for the condition with $8 \mathrm{sccs} \mathrm{SiH}_{4}$ also temperatures of 400 and $500{ }^{\circ} \mathrm{C}$ were applied. This condition with 8 sccs $\mathrm{SiH}_{4}$ was explored in more detail because it turned out (see below) that this condition yields similar Sirich material as the $a-\mathrm{SiN}_{x}: \mathrm{H}$ deposited at ISFH with a record low surface recombination velocity. 4

In Fig. 8, the effective minority carrier lifetime is given for the substrates coated with $a-\mathrm{SiN}_{x}: \mathrm{H}$ under the different conditions. Data as obtained after treatment of the coated substrates with a forming gas anneal for 10 and $20 \mathrm{~min}$ at $400{ }^{\circ} \mathrm{C}$ are also given. The bias illumination level of the samples was $50 \mathrm{~mW} / \mathrm{cm}^{2}$. The figure shows that the effective lifetimes obtained are rather low corresponding with a relatively high surface recombination velocity of the charge carriers and therefore with a low degree of surface passivation. The effective lifetime shows however a slight optimum for the samples deposited with $8 \operatorname{sccs} \mathrm{SiH}_{4}$. As addressed below, the structural properties of the $a-\mathrm{SiN}_{x}: \mathrm{H}$ under these conditions are comparable to those of the ISFH material with record low surface recombination. The highest effective life- 


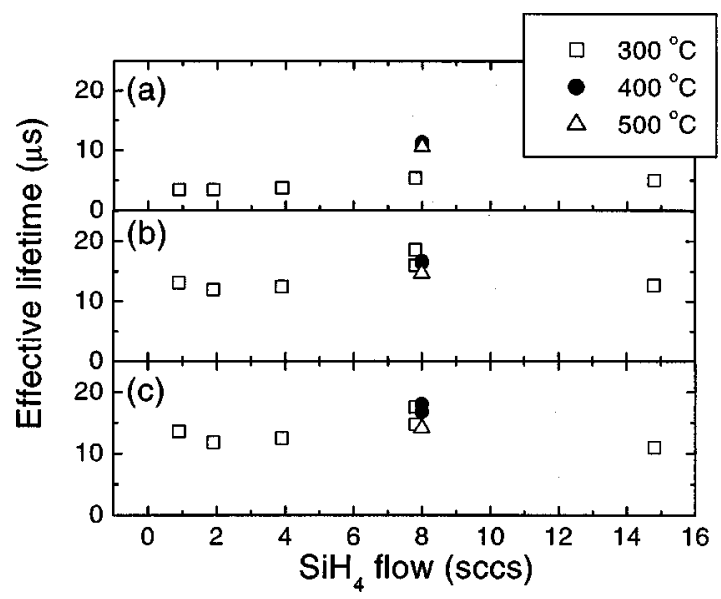

FIG. 8. Effective minority carrier lifetime under $50 \mathrm{~mW} / \mathrm{cm}^{2}$ bias illumination for $a-\mathrm{SiN}_{x}: \mathrm{H}$ films deposited by the ETP technique for different substrate temperatures and $\mathrm{SiH}_{4}$ flows. The $\mathrm{H}_{2}$ flow is 5 sccs. The figure shows results (a) for as-deposited films, (b) for films after a 10 min anneal at $400{ }^{\circ} \mathrm{C}$, and (c) for films after $20 \mathrm{~min}$ anneal at $400{ }^{\circ} \mathrm{C}$.

time (i.e., $18 \mu \mathrm{s}$ ) obtained for this condition corresponds with an effective surface recombination velocity slightly lower than $10^{3} \mathrm{~cm} / \mathrm{s}$. This is much higher than the record low surface recombination velocity of $4 \mathrm{~cm} / \mathrm{s}$ (corresponding to an effective lifetime of $1.6 \mathrm{~ms})^{4}$ obtained with RPECVD coated cells after a forming gas anneal for $10 \mathrm{~min}$ at $400^{\circ} \mathrm{C}$.

The results reveal that the ETP $a-\mathrm{SiN}_{x}: \mathrm{H}$ deposited with a $\mathrm{SiH}_{4}$ flow of $8 \mathrm{sccs}$ yields the highest effective lifetime. Comparing this film's structural properties with those of the ISFH RPECVD deposited $a-\mathrm{SiN}_{x}: \mathrm{H}$ with a record low surface recombination velocity yields the following similarities: the refractive index of both the ETP deposited $a-\mathrm{SiN}_{x}: \mathrm{H}$ as well as of the ISFH material has a refractive index of $\sim 2.3 .{ }^{13}$ The N/Si ratio is 0.7 and the hydrogen content is $17 \%$ while for the ISFH $a-\mathrm{SiN}_{x}: \mathrm{H}$ these are between $0.7-0.8$ and $16 \%-$ $18 \%$, respectively. The total mass density is however lower for the ETP $a-\mathrm{SiN}_{x}: \mathrm{H}\left(2.2 \mathrm{~g} / \mathrm{cm}^{3}\right.$ in comparison with about $2.6 \mathrm{~g} / \mathrm{cm}^{3}$ ) indicating that the ETP deposited films may contain voids which possibly contribute to carrier recombination. The hydrogen bonding configuration is similar for both materials: almost no absorption due to $\mathrm{NH}$ vibrations (only very weak peak at the stretching frequencies) is observable and the hydrogen is mainly bonded as $\mathrm{H}-\mathrm{Si}-\mathrm{N}_{2} \mathrm{Si}$ and/or $\mathrm{H}_{2}-\mathrm{Si}-\mathrm{NSi}$. The peak positions for the $\mathrm{SiH}$ absorptions are somewhat lower in the ETP deposited material indicating that this material contains slightly less nitrogen. ${ }^{31,37}$ The ETP deposited $a-\mathrm{SiN}_{x}: \mathrm{H}$ is apparently relatively similar to the ISFH material, but despite these similarities, there is a large discrepancy in surface recombination velocities. The main difference is the deposition rate which is $20 \mathrm{~nm} / \mathrm{s}$ for the ETP deposited material and only $0.25-0.5 \mathrm{~nm} / \mathrm{s}$ for ISFH material deposited by rf PECVD and $\sim 1 \mathrm{~nm} / \mathrm{s}$ for ISFH $a-\mathrm{SiN}_{x}: \mathrm{H}$ deposited by RPECVD.

The lack of surface passivation obtained by the ETP deposited $a-\mathrm{SiN}_{x}: \mathrm{H}$ can either be a interface or bulk effect. To track down this problem, the following experiment has been conducted: samples were coated by a stack of two $a-\mathrm{SiN}_{x}: \mathrm{H}$

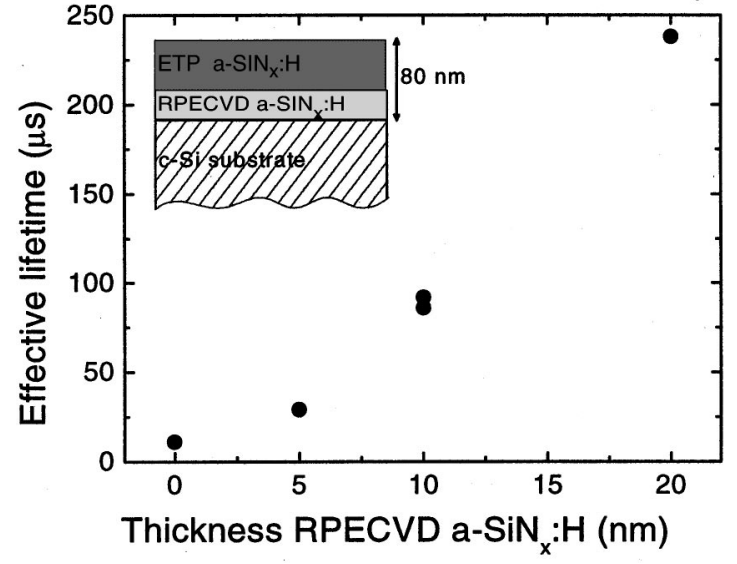

FIG. 9. Effective minority carrier lifetime for $a-\mathrm{SiN}_{x}: \mathrm{H}$ films consisting of a stack of ETP deposited $a-\mathrm{SiN}_{x}: \mathrm{H}$ on top of ISFH remote microwavedeposited $a-\mathrm{SiN}_{x}: \mathrm{H}\left(\mathrm{RPECVD} a-\mathrm{SiN}_{x}: \mathrm{H}\right)$. The thickness of the RPECVD $a-\mathrm{SiN}_{x}: \mathrm{H}$ has been varied between 0 and $20 \mathrm{~nm}$, the total $a-\mathrm{SiN}_{x}: \mathrm{H}$ thickness is $\sim 80 \mathrm{~nm}$. The ETP conditions are $5 \operatorname{sccs} \mathrm{H}_{2}, 8 \operatorname{sccs} \mathrm{SiH}_{4}$, and a substrate temperature of $400{ }^{\circ} \mathrm{C}$.

films. The bottom film directly on top of the sample, was deposited by RPECVD and has a thickness of either $0,5,10$, or $20 \mathrm{~nm}$ (deposition rate: $\sim 1 \mathrm{~nm} / \mathrm{s}$ ). The top film was deposited by the ETP technique using the above mentioned condition with $8 \mathrm{sccs} \mathrm{SiH}_{4}$ (deposition rate: $20 \mathrm{~nm} / \mathrm{s}$ ) and its thickness was adjusted such that the total silicon nitride film thickness is about $80 \mathrm{~nm}$. Figure 9 shows the effective lifetime obtained for these samples which clearly increases with increasing RPECVD film thickness. The figure shows that an effective lifetime of $238 \mu$ s can be obtained by a combination of $20 \mathrm{~nm}$ RPECVD and $60 \mathrm{~nm}$ ETP deposited $a-\mathrm{SiN}_{x}: \mathrm{H}$. This corresponds to an effective surface recombination velocity as low as $55 \mathrm{~cm} / \mathrm{s}$.

Important is, however, the increase of the effective lifetime with increasing thickness of the RPECVD material. This effect suggests that the lack of surface passivation for the ETP material is a bulk problem and it might therefore be correlated with the above mentioned lower atomic density of the ETP deposited films. An explanation by, e.g., contamination of the film by metal atoms (possibly originating from the cathodes of the plasma source) is unlikely because no metal contamination has been observed by nuclear profiling techniques (Rutherford backscattering with a detection limit $<10^{13} \mathrm{~cm}^{-2}$ ).

As mentioned, for most industrial-type solar cells surface passivation is at the moment a much less important issue than for example antireflection performance and bulk passivation. This is also due to the fact that most of these cells have a diffused emitter for which the effect of surface passivation is already reduced. ${ }^{5}$ To test the effective minority carrier lifetime of the ETP deposited $a-\mathrm{SiN}_{x}: \mathrm{H}$ under these more industrially relevant conditions, lifetime measurements were carried out on phosphorous-diffused emitter samples having a sheet resistance of $40 \Omega / \mathrm{sq}$ (at both sides). The $a-\mathrm{SiN}_{x}: \mathrm{H}$ was deposited at both sides of the samples using the same conditions as mentioned above (i.e., 8 sccs $\mathrm{SiH}_{4}$ 
and at a substrate temperature of $400{ }^{\circ} \mathrm{C}$ ). This yielded an effective lifetime of $23 \mu$ s which is now indeed much closer to lifetime of the RPECVD deposited samples of $200 \mu$ s.

\section{Bulk passivation}

After the antireflection working, bulk passivation of the silicon is the most important feature of $a-\mathrm{SiN}_{x}: \mathrm{H}$ coatings for industrial-type solar cells so far. To reduce material costs, these type of cells are (in the future) mostly not made from good quality monocrystalline-silicon but from lower quality casted multicrystalline and edge-defined film fed grown (EFG) silicon ribbons. These silicon materials contain crystallographic defects such as grain boundaries and intra-grain defects (e.g., dislocations, twins) which act as carrier recombination centers and consequently reduce the minority carrier lifetime significantly. Hydrogen in the $a-\mathrm{SiN}_{x}: \mathrm{H}$ coating can passivate these defects when the hydrogen is made mobile by thermal activation of the film, e.g., in the firing process of the cell's screen printed metallization. $6,7,44$

Although previous measurements have suggested bulk passivation by ETP deposited $a-\mathrm{SiN}_{x}: \mathrm{H},{ }^{43}$ a new experiment was carried out to obtain more evidence. Two groups of 10 Baysix mc-Si wafers $\left(10 \times 10 \mathrm{~cm}^{2}\right)$ were selected such that adjacent positions in the ingot (neighbor wafers) were equally divided over the two groups. One group of wafers was processed into solar cells using the standard process scheme at ECN Solar Energy: saw damage etch, emitter diffusion (50 $\Omega / \mathrm{sq}$ emitter), phosphorous glass removal, $a$-SiN $x$ :H deposition, Ag-front side and Al-rear side metallization by screen printing, and simultaneous firing of the metal contacts at both sides in a belt furnace. The deposition process of the $a-\mathrm{SiN}_{x}: \mathrm{H}$ was carried out by the ETP technique using the conditions: $45 \mathrm{~A}$ arc current, 55 sccs $\mathrm{Ar}, 5$ sccs $\mathrm{H}_{2}, 10 \operatorname{sccs} \mathrm{N}_{2}, 4 \operatorname{sccs} \mathrm{SiH}_{4}$, and a substrate temperature of $350{ }^{\circ} \mathrm{C}$. The distance between cascaded arc plasma source and substrate was $70 \mathrm{~cm}$ and the resulting refractive index and deposition rate of the $a-\mathrm{SiN}_{x}: \mathrm{H}$ were 2.11 and 9.2 $\mathrm{nm} / \mathrm{s}$, respectively. The second group of wafers was processed by the same scheme except for the fact that the $a-\mathrm{SiN}_{x}: \mathrm{H}$ deposition (with the same deposition conditions) was carried out after the screen-printing and firing of the metallization. This is the so-called reverse-scenario process and it serves as a reference: the $a-\mathrm{SiN}_{x}: \mathrm{H}$ coating leads in principle to a similar antireflection coating performance but it cannot induce bulk passivation because the $a-\mathrm{SiN}_{x}: \mathrm{H}$ is not thermally activated in the firing process.

The bulk passivation was examined by internal quantum efficiency (IQE) measurements and not by considering the solar cell performance parameters (often the open-circuit voltage $V_{\text {oc }}$ of the cell is used as a fingerprint of bulk passivation of mc-Si solar cells) because the homogeneity of the coatings is reasonable but not yet sufficient for this (see Sec. III B). The IQE was determined by quantum efficiency and reflectivity measurements at the $5 \times 5 \mathrm{~cm}^{2}$ center region of the cells. Results of one set of cells (neighbor wafers) are given in Fig. 10(a). In Fig. 10(b) the IQE of both cells is displayed relative to the IQE of the reverse-scenario cells

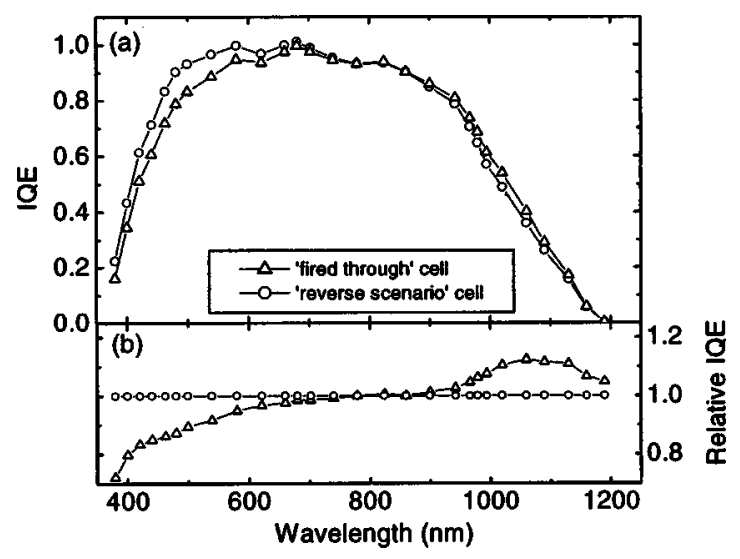

FIG. 10. (a) Internal quantum efficiency (IQE) measurements of mc-Si cells made from neighbor mc-Si wafers and coated with an ETP $a-\mathrm{SiN}_{x}: \mathrm{H}$ antireflection coating. For the fired through cell, the $a-\mathrm{SiN}_{x}: \mathrm{H}$ has been deposited before screenprinting and firing of the front and rear side metallization. The $a-\mathrm{SiN}_{x}: \mathrm{H}$ has therefore been thermally activated during the firing step in a belt furnace. For the reverse scenario cell, the $a-\mathrm{SiN}_{x}: \mathrm{H}$ has been deposited after the screenprinting and firing of the front and rear side metallization. The $a-\mathrm{SiN}_{x}: \mathrm{H}$ for this cell has therefore not been thermally activated. (b) IQE of both cells relative to the IQE of the reverse scenario cells.

showing the difference between two different cells. The figure shows an enhancement of the red response for the "fired through" cell compared to the reverse-scenario cell which clearly shows that bulk passivation is obtained for the highrate deposited $a-\mathrm{SiN}_{x}: \mathrm{H}$. This is confirmed by the other cells in the group which have revealed similar data. On the other hand, the blue response of the fired through cell has decreased significantly compared to the reverse-scenario cell. This is an interesting effect which is of course unfavorable to the performance of the cells. It appears that the $a-\mathrm{SiN}_{x}: \mathrm{H}$ coating used is very sensitive to heat treatment and on the basis of the reflectivity measurements of the cells it is deduced that the decrease in blue response is most probably due to densification of the material in the firing step. This causes an increase of the absorption coefficient of the $a-\mathrm{SiN}_{x}: \mathrm{H}$ and leads therefore to a lower internal quantum efficiency in the lower wavelength region. ${ }^{45}$ In summary, it can be concluded that bulk passivation has been observed for the very high-rate deposited $a-\mathrm{SiN}_{x}: \mathrm{H}$. Nonetheless, the application of the bulk passivating, high-rate deposited $a$-SiN $x: \mathrm{H}$ antireflection coating on large, industrial-type cells appears still to be hindered by insufficient homogeneity and significant light absorption after firing. These problems might however relatively easily be solved technologically. In future work, we will address these remaining problems of the ETP deposited $a-\mathrm{SiN}_{x}: \mathrm{H}$ by a deeper analysis of the optical properties and by investigation of the influence of the thermal activation of the $a-\mathrm{SiN}_{x}: \mathrm{H}$, as well as by the application of $\mathrm{NH}_{3}$ as nitrogen source gas instead of $\mathrm{N}_{2}$.

\section{CONCLUSIONS}

The feasibility of high-rate deposition of $a-\mathrm{SiN}_{x}: \mathrm{H}$ by the expanding thermal plasma technique has been examined with respect to its potential of high-throughput processing of 
functional antireflection coatings on crystalline silicon solar cells. For gas mixtures of $\mathrm{Ar}, \mathrm{H}_{2}, \mathrm{~N}_{2}$, and $\mathrm{SiH}_{4}$, the structural and compositional properties that can be obtained for the $a-\mathrm{SiN}_{x}: \mathrm{H}$ have been mapped and the film homogeneity, antireflection performance, and surface and bulk passivation have been investigated. The most important conclusions in this respect are:

(1) Very high deposition rates $(10-20 \mathrm{~nm} / \mathrm{s})$ of the $a-\mathrm{SiN}_{x}: \mathrm{H}$ can be obtained by the expanding thermal plasma.

(2) The refractive index and the N/Si ratio in the film can fully be tuned for optimum antireflection coating performance by varying the $\mathrm{SiH}_{4}$ flow with respect to the $\mathrm{N}_{2}$ flow.

(3) The hydrogen content is mainly determined by the substrate temperature and is in the range of $16 \%-18 \%$ for films deposited at $400{ }^{\circ} \mathrm{C}$. This hydrogen concentration is similar in magnitude compared to $a-\mathrm{SiN}_{x}: \mathrm{H}$ films deposited by other techniques and which induce bulk passivation of multicrystalline or ribbon silicon solar cells.

(4) Investigation of the film homogeneity has revealed that the homogeneity can be improved by increasing the plasma source-substrate distance at the expense of the deposition rate $(30 \%$ decrease when going from 35 to 70 $\mathrm{cm})$. For the increased plasma source-substrate distance the thickness homogeneity is $<8 \%$ within wafer for 10 $\times 10 \mathrm{~cm}^{2}$ cells and $<2 \%$ within wafer for the refractive index. Although this thickness homogeneity is reasonable, it is not yet sufficient, but can be improved by other reactor designs.

(5) Good antireflection coating performance has been observed for the $a-\mathrm{SiN}_{x}: \mathrm{H}$ as has been tested for small area monocrystalline silicon solar cells. The solar cells' average efficiency increased from $12.7 \%$ to $17.7 \%$ by application of the ETP deposited $a-\mathrm{SiN}_{x}: \mathrm{H}$. This is only $0.55 \%$ (absolute) lower than for ISFH reference cells with high-quality $a-\mathrm{SiN}_{x}: \mathrm{H}$ and this difference can be attributed to lack of surface passivation of the ETP deposited $a-\mathrm{SiN}_{x}: \mathrm{H}$.

(6) The lack of surface passivation has also been revealed by lifetime measurements on both float zone, low-resistivity silicon and diffused emitter samples. For the float zone silicon samples, the lowest effective surface recombination velocity obtained is slightly lower than $1000 \mathrm{~cm} / \mathrm{s}$ which is far above the record-low surface recombination velocity of $4 \mathrm{~cm} / \mathrm{s}$. On the more industrial-type diffused emitter samples this difference is significantly smaller. The lack of good surface passivation of the $a-\mathrm{SiN}_{x}: \mathrm{H}$ coatings, which have rather similar structural and compositional film properties as the material with very good surface passivation, has been investigated. This has indicated that this lack is due to a problem in the $a-\mathrm{SiN}_{x}: \mathrm{H}$ bulk material instead of an interface problem.

(7) Bulk passivation experiments in which cells with thermally activated $a-\mathrm{SiN}_{x}: \mathrm{H}$ have been compared to cells without thermally activated $a-\mathrm{SiN}_{x}: \mathrm{H}$ have revealed a clear enhancement of the internal quantum efficiency in the high-wavelength region. Bulk passivation has therefore been observed for the high-rate $a-\mathrm{SiN}_{x}: \mathrm{H}$ although an insufficient film homogeneity and a decrease of the blue response in the internal quantum efficiency (due to the thermal activation of the material) pose still some (technological) problems.

The potential of $a-\mathrm{SiN}_{x}: \mathrm{H}$ deposited at very high rates by the expanding thermal plasma has therefore been demonstrated by this first study and will be explored more extensively in future work.

\section{ACKNOWLEDGMENTS}

The experiments on the film homogeneity and bulk passivation have been carried out within the E.E.T. program by the Netherlands Ministry of Economic Affairs, the Ministry of Education, Culture and Science and the Ministry of Public Housing, Physical Planning and Environment in the project "Sunovation." H. Rieffe of ECN Solar Energy is gratefully acknowledged for the IQE measurements, Dr. W. Arnold Bik of the Utrecht University for the ERD analysis, and A. H. M. Smets for the ellipsometry measurements. The technicians M. J. F. van de Sande, J. F. C. Jansen, A. B. M. Hüsken, and H. M. M. de Jong are acknowledged for their skillful technical assistance.

${ }^{1}$ A. Grill, Cold Plasma in Materials Fabrication (IEEE New York, 1994). ${ }^{2}$ A. G. Aberle, T. Lauinger, and R. Hezel, Proceedings of the 14th European Photovoltaic Solar Energy Conference, Barcelona, 1997, p. 684.

${ }^{3}$ A. G. Aberle, Sol. Energy Mater. Sol. Cells 65, 239 (2001).

${ }^{4}$ T. Lauinger, J. Schmidt, A. G. Aberle, and R. Hezel, Appl. Phys. Lett. 68, 1232 (1996)

${ }^{5}$ J. D. Moschner, P. Doshi, D. S. Ruby, T. Lauinger, A. G. Aberle, and A. Rohatgi, Proceedings of the 2nd World Photovoltaic Solar Energy Conference, Vienna, 1998, p. 1894.

${ }^{6}$ R. Lüdemann, Mater. Sci. Eng., B 58, 86 (1999).

${ }^{7}$ J.-W. Jeong, M. D. Rosenblum, J. P. Kalejs, and A. Rohatgi, J. Appl. Phys. 87, 7551 (2000).

${ }^{8}$ A. Rohatgi, Z. Chen, P. Sana, N. Evers, P. Loglen, and R. A. Steeman, Optoelectron., Devices Technol. 9, 523 (1994).

${ }^{9}$ C. Boehme and G. Lucovsky, J. Appl. Phys. 88, 6055 (2000).

${ }^{10}$ J. Szlufcik, F. Duerincks, E. van Kerschaver, R. Einhaus, A. Ziebakowski, E. Vazsonyi, K. de Clerq, J. Horzel, L. Frisson, J. Nijs, and R. Mertens, Proceedings of the 14th European Photovoltaic Solar Energy Conference, Barcelona, 1997, p. 380.

${ }^{11}$ W. J. Soppe, B. G. Duivelaar, S. E. A. Schiermeier, A. W. Weeber, A. Steiner, and F. M. Schuurmans, Proceedings of the 16th European Photovoltaic Solar Energy Conference, Glasgow, 2000, p. 1420.

${ }^{12}$ M. Green, Solar Cells: Operating Principles, Technology, and System Applications (Prentice Hall, Englewood Cliffs, NJ, 1982); P. Doshi, G. E. Jellison, Jr., and A. Rohatgi, Appl. Opt. 36, 7826 (1997).

${ }^{13}$ T. Lauinger, J. Moschner, A. G. Aberle, and R. Hezel, J. Vac. Sci. Technol. A 16, 530 (1998).

${ }^{14} \mathrm{An}$ interesting exception to this general trend has been reported in $\mathrm{J}$. Schmidt and M. Kerr, Sol. Energy Mater. Sol. Cells 65, 585 (2001).

${ }^{15}$ J. Robertson, Philos. Mag. B 63, 47 (1991).

${ }^{16}$ W. J. Soppe, C. Devilée, S. E. A. Schiermeier, J. Hong, W. M. M. Kessels, M. C. M. van de Sanden, W. M. Arnoldbik, and A. W. Weeber, Proceedings of the 17th European Photovoltaic Solar Energy Conference, Munich, 2001 (accepted).

${ }^{17}$ G. Lucovsky, P. D. Richard, D. V. Tsu, S. Y. Lin, and R. J. Markunas, J. Vac. Sci. Technol. A 4, 681 (1986).

${ }^{18}$ T. Lauinger, A. G. Aberle, and R. Hezel, Proceedings of the 14th European Photovoltaic Solar Energy Conference, Barcelona, 1997, p. 853.

${ }^{19}$ F. M. Schuurmans, Ph.D. thesis, Utrecht University, 1998.

${ }^{20}$ J. Schmidt and A. G. Aberle, J. Appl. Phys. 85, 3626 (1999). 
${ }^{21}$ F. M. Schuurmans (private communication).

${ }^{22}$ H. Nagel, J. Schmidt, A. G. Aberle, and R. Hezel, Proceedings of the 14th European Photovoltaic Solar Energy Conference, Barcelona, 1997, p. 762.

${ }^{23}$ W. Soppe, A. Weeber, H. de Moor, W. Sinke, T. Lauinger, T. Auer, B. Lenkeit, and A. Aberle, Proceedings of the 2nd World Photovoltaic Solar Energy Conference, Vienna, 1998, p. 1826.

${ }^{24}$ D. C. Schram and G. M. W. Kroesen, U.S. Patent No. 4,871,580 (1989), European Patent No. 0297637 (1992).

${ }^{25}$ J. W. A. M. Gielen, W. M. M. Kessels, M. C. M. van de Sanden, and D. C. Schram, J. Appl. Phys. 82, 2643 (1997).

${ }^{26}$ W. M. M. Kessels, R. J. Severens, A. H. M. Smets, B. A. Korevaar, G. J. Adriaenssens, D. C. Schram, and M. C. M. van de Sanden, J. Appl. Phys. 89, 2404 (2001).

${ }^{27}$ J. J. Beulens, M. J. de Graaf, and D. C. Schram, Plasma Sources Sci. Technol. 2, 180 (1993).

${ }^{28}$ W. M. M. Kessels, C. M. Leewis, M. C. M. van de Sanden, and D. C. Schram, J. Appl. Phys. 86, 4029 (1999).

${ }^{29}$ W. M. M. Kessels, F. J. H. van Assche, J. Hong, D. C. Schram, and M. C. M. van de Sanden (to be published).

${ }^{30}$ M. C. M. van de Sanden, R. J. Severens, W. M. M. Kessels, L. J. van IJzendoorn, and D. C. Schram, Mater. Res. Soc. Symp. Proc. 467, 621 (1997).

${ }^{31}$ E. Bustarret, M. Bensouda, M. C. Habrard, J. C. Bruyère, S. Poulin, and S. C. Gujrathi, Phys. Rev. B 38, 8171 (1988).

${ }^{32}$ W. M. Arnold Bik and F. H. P. M. Habraken, Rep. Prog. Phys. 56, 859 (1993).
${ }^{33}$ A. W. Stephens, A. G. Aberle, and M. A. Green, J. Appl. Phys. 75, 1611 (1994).

${ }^{34}$ W. A. Langford and M. J. Rand, J. Appl. Phys. 49, 2473 (1978).

${ }^{35}$ V. J. Kapoor and R. S. Bailey, J. Vac. Sci. Technol. A 1, 600 (1983).

${ }^{36}$ M. M. Guraya, H. Ascolani, G. Zampieri, J. I. Cisneros, J. H. Dias da Silva, and M. P. Cantão, Phys. Rev. B 42, 5677 (1990).

${ }^{37}$ D. V. Tsu, G. Lucovsky, and M. J. Mantini, Phys. Rev. B 33, 7069 (1986).

${ }^{38}$ F. Demichelis, F. Giorgis, and C. F. Pirri, Philos. Mag. B 74, 155 (1996).

${ }^{39}$ K.-C. Lin and S.-C. Lee, J. Appl. Phys. 72, 5474 (1992).

${ }^{40}$ G. Dupont, H. Caquineau, B. Despax, R. Berjoan, and A. Dollet, J. Phys. D 30, 1064 (1997).

${ }^{41}$ F. Giorgis, F. Giuliani, C. F. Pirri, and E. Tresso, in Properties of Amorphous Silicon and its Alloys, edited by Time Searle (Inspec, The Institution of Electrical Engineers, London, 1998), p. 85.

${ }^{42}$ W. M. M. Kessels, M. G. H. Boogaarts, J. P. M. Hoefnagels, D. C. Schram, and M. C. M. van de Sanden, J. Vac. Sci. Technol. A 19, 1027 (2001).

${ }^{43}$ W. M. M. Kessels, F. J. H. van Assche, J. Hong, J. D. Moschner, T. Lauinger, D. C. Schram, and M. C. M. van de Sanden, Mater. Res. Soc. Symp. Proc. 664, A.8.6.1. (2001)

${ }^{44}$ Z. Chen, A. Rohatgi, R. O. Bell, and J. P. Kalejs, Appl. Phys. Lett. 65, 2078 (1994).

${ }^{45}$ In principle, the IQE should not be sensitive to absorption in the AR coating, however, in the commonly applied experimental procedure reflectivity measurements are used to determine the IQE. 